\title{
Uncovering language policy in higher education: Reflections from the classroom
}

\author{
Carmina Makar \\ The City College of New York, USA \\ Article received 26 May 2016, accepted 31 May 2016, final version 31 May 2016 \\ DOI: http://dx.doi.org/10.5565/rev/jt13.675
}

\begin{abstract}
This paper analyzes salient issues that emerged over the course of a language policy action research course at the Graduate Center City University in New York. The course, embedded in the larger scope of the Futures Initiatives, allowed students to study different language communities across different campuses in New York. This piece describes these findings in light of language policy and higher education in super diverse contexts and argues for further exploration of language practices to inform the work of educators across different settings in higher education.
\end{abstract}

Keywords: language policy, multilingualism, language practices, higher education

\section{Resumen}

Este trabajo analiza a través de distintos lentes temáticos, la experiencia de trabajo en un curso de política lingüística en el Graduate Center en la Universidad de Nueva York. Dicho curso formo parte de la Iniciativa para el Futuro, y permitió a los estudiantes investigar comunidades lingüísticas en diferentes campus de educación superior en la ciudad de Nueva York. Este articulo describe sus hallazgos a la luz de los actuales estudios de política lingüística en educación superior, específicamente en contextos de gran diversidad, y promueve mayor estudio de políticas y practicas lingüísticas para informar el trabajo de educadores en distintas disciplinas en la educación superior.

Palabras clave: política lingüística, multilingüismo, prácticas lingüísticas, educación universitaria

\section{Resum}

Aquest article analitza, a través de diferents aproximacions temàtiques, l'experiència de treball en una assignatura de política lingüística al Graduate Center de la Universitat de Nova York. Aquesta assignatura va formar part de la Iniciativa per al Futur, i va permetre als estudiants portar a terme recerques sobre comunitats lingüístiques en diferents campus d'educació superior a la ciutat de Nova York. Aquest article descriu les seves troballes a la llum dels actuals estudis de política lingüística en educació superior, específicament en contextos de gran diversitat. Es reclamen futures recerques sobre polítiques i pràctiques lingüístiques per informar la tasca docents en les diferents disciplines en l'educació superior. 
Paraules clau: política lingüística, multilingüisme, pràctiques lingüístiques, educació universitària

\section{Introduction}

The body of work featured in this special issue is the result of a collective research endeavor that emerged in the context of a course held at the Graduate Center of the City University of New York (CUNY). Global Perspectives on Language and Education Policy, co-taught by Prof. Ofelia Garcia and myself, engaged students in critically thinking about language policies in society and education and their connection to sociopolitical ideologies in different nation-states (García, 2015). In particular, language education policy examines the influence of colonial, regional and global languages, and explores how states manage and develop linguistic resources (Tollefson, 2013).

The course was part of The Futures Initiative ${ }^{I}$, a hub housed at the Graduate Center whose mission is to better equip graduate students to develop engaged critical pedagogical practices and translate specialized research into teaching throughout the University. CUNY provides accessible education at 24 campuses across New York City, in an integrated system of senior and community colleges, graduate and professional schools, research centers, institutes and consortia. It's mission of access has served a deeply diverse community since it was founded as a Free Academy in 1847, and then established as a Ph.D.-granting institution in 1961, when it became the model for the modern public university (CUNY, 2016).

Today it continues to serve as a national model of quality and access. In this context, the Futures Initiative aims to establish dialogue among the different colleges in the system and prepare graduate students to better serve the needs of the diverse population of students, in particular the undergraduate population, which is the group doctoral students tend to work with as teachers. As part of their mission, the Futures Initiative launched a series of team taught courses that paired senior and junior scholars from across the board to come together and teach a course in their area of specialty with a social justice orientation.

As part of our membership in the Futures Initiative, one of the goals for the seminar on Global Language Policy was to develop an action research project that would explore different language practices throughout the different colleges in the CUNY system. The value of exploring 
linguistic communities and practices quickly became apparent as stories began to emerge. The affiliation of our course to the Futures Initiative was a relevant factor in shaping our collective research agenda for the term and defining mechanisms of public engagement.

\section{Point of Departure: Multilingual CUNY}

As we dived into the literature on global language policy, we prompted students in the Global Perspectives on Language and Education Policy course to make connections to their local context, in particular, to the different colleges across the CUNY system. The group engaged in critical discussions around the multilingual characteristics of the student population and the way the literature situates multilingual practices. As our understanding of the phenomena evolved, we began to 'case the joint'. We found a paucity of research around language policy and higher education. Multilingualism in higher education, particularly in the US context, has been explored predominantly though the lens of foreign languages versus English. The discursive appropriation of foreign perpetuates the notion that languages other than English are something that exist outside the realm of our students' lives, that they are not organic to their history and their identities, that there is a division and an ongoing process of othering, and that these languages exist only within the cadre of English hegemony.

Vila and Bretxa (2014) noted this trend and assert that globalization and the commodification of knowledge are shaping the linguistic configuration of higher education, as they bring attention to medium-sized languages that have achieved the status of lingua academica. Their volume compares the trajectories of languages that have found a place higher education and others that have not. Their framework is a powerful lens to think through these issues and go beyond the dichotomy of English and foreign languages to understand the complex dynamisms of language policy and practices in superdiverse environments such as the CUNY system in New York City. The students in our course on language and education policy found the network of colleges a fertile laboratory to explore linguistic practices and situate different language communities at the intersection of local histories and identities.

\section{Methodology}

Over the course of the project, we grappled with the best way to grasp linguistic practices in a situated manner. Testing ethnographic techniques shed light on some of the nuances unique to 
exploring language policy. How best to approach subjects and illuminate underlying policies and practices? One of the features explored was the use of oral history to outline and emphasize the intersections between language, personal history and identity. Students had a flexible repertoire of data collection techniques they used in alignment with their research questions. The process of "capturing language practices" and making them visible highlighted multiple ecosystems of linguistic ethnography, which were enriched by the diversity of the cases and contexts of each particular project. Students' emerging awareness and methodological sensibility was a relevant pedagogical yield of the process.

Linguistic ethnography, as a longstanding tradition, has sought to develop an epistemological understanding of language and social life. Some scholars however, have noted the need to strengthen the methodological emphasis on language policy: "While theoretical conceptualizations of language policy have grown increasingly rich, empirical data that test these models are less common. Further, there is little methodological guidance for those who wish to do research on language policy interpretation and appropriation" (Johnson, 2009, p. 139). Ricento (2000) further emphasizes the need to connect micro level interaction with macro level policy, which these cases studies sought to do.

The discussions around method drove an important connection between the theoretical underpinnings explored in the classroom and the windows of analysis proposed for each case study. Methodological considerations illuminated the need to develop finer tools to envision, capture and analyze policy as it relates to multiple languages, and in particular, to capture the process of policy trickling down to language ideologies and language practice. A hybrid ethnographic approach with the use of oral history resulted in relevant pockets of linguistic intersection by winding in the interpretive approaches at the heart of the interdisciplinary nature of the class.

\section{Pedagogical exploration}

A valuable feature of the research process was the evolving connection to students' meta pedagogical reflection. The theoretical framework and its resulting methodological approach emerged in the context of the seminar, which included 17 candidates from different disciplines, all in the humanities, working in fields connected to language studies. Four of the participants in the seminar were visiting scholars. This diverse configuration nourished the collective 
interpretation of the theories and deeply shaped the work conducted. The dialogue that was established provided open guidelines for the development of the students' research questions and an outlet for students to share the progress of their data collection as their research evolved.

The pedagogical guidelines in the classroom mirrored ethnographically oriented practices and allowed the participants to carve out their methodological approach on the ground. The theories that undergirded our work throughout the course pointed to global practices and illuminated colonial legacies that shape language planning efforts today. The use of case studies provided geographical and topical considerations that enabled students to strengthen the connections they made in the field.

The use of oral history to identify language policy features gave agency to the research participants and located them at the center of the policy making process. As the articles in this volume show, participants are at the core of the sociolinguistic forces shaping language planning efforts in their communities, and as it happens in contemporary ethnographic tradition, participants developed a discursive awakening as they shared their experiences of inclusion or inclusion vis-à-vis multiple language practices.

Findings from the collection of studies point to the many challenges multilingual students face in their educational trajectory. Many of these concerns merit further questions and study, but they have provided researchers with substantial knowledge about their undergraduate population that will strongly inform their pedagogical practice. Sharing their language experiences empowers students to be more vocal about the spaces they need in order to authentically engage in language communities, position their languages, learn more about their histories, validate their multilingual identities and shape local educational policy to visibilize the many languages other then English that are spoken throughout the CUNY system. This visibility should not solely be at the curricular level, but also on the social front, including legitimizing mechanisms to counteract misconceptions around language and identity.

This special issue contributes insights on two fronts. First, it speaks to the literature on language policy and higher education by furthering our thinking around language interaction at institutions of higher education with multilingual populations. While language policy in the context of higher education institutions tends to focus on the role of English, these case studies highlight how multilingual societies host dynamic multilingual practices that go beyond foreign 
language studies and are critical to our understanding of pedagogy, history and identity. These case studies also engage in methodological dialogue as we continue to think about the best ways to capture language in action through policy, ideology and practice.

Second, findings from this work make a substantial pedagogical contribution. How can they inform our practice as educators of multilingual populations in higher education? Furthermore, what we can learn from non-formal language education practices taking place in diverse pockets within our institutions of higher education? Drawing from my analysis of the works in this volume as well as my experience as co-instructor of the course, along with Ofelía Garcia, I offer the following practical insights.

\section{Insights from the field: harnessing multilingualism as an asset in the classroom}

In the US, historical and political structures behind the embodiment of English Only discourses are compounded with theorizing that considers speakers of other languages as de facto disadvantaged. This view has been described in the literature as deficit theorizing or deficit paradigms (Carter \& Goodwin, 1999). These internalized policies frame multilingual students as problems to be fixed. Salient findings from the collection of case studies highlight rich language practices and the potential for educators to develop pedagogies that draw on these languages as an asset.

As revealed in these studies findings, educators share an understanding that there is work yet to be done to better equip faculty to teach through the strengths of linguistically diverse populations. How to bring in students' background and language into the classroom? What kinds of strategies and creative processes can educators engage in? How to alleviate the stigma students feel by using their own languages? The following personal vignettes highlight students' malaise around perceived language attitudes:

"I am asked where I'm from, but I was born here..."

"I was once asked by a teacher if I spoke Egyptian..."

"People clump me together with Japanese, Korean or other..."

"In a class with focus on diverse learners, all the examples were for Spanish-speakers..."

"They focus too much on improving my English proficiency..."

Bellaterra Journal of Teaching \& Learning Language \& Literature. 9.2 (May-June 2016) ISSN 2013-6196 
"I speak four languages. I've never once been asked to talk about them or bring them in as a resource, and I'm training to be a teacher..."

In this context, I propose a three-pronged approach to celebrating language in the classroom: examination of our syllabus, our pedagogy and our assessment strategies. A syllabus is alive, it is also a piece of scholarship, and like language, it is performative, it portrays a stance, it can be inclusive or exclusive. What languages have I used in the syllabus? Are my students represented, can they see themselves there? How can my syllabus harness the value of linguistically and culturally diverse students? What modifications might it need?

In terms of pedagogy, students benefit from multiple entry-points to access content. We need a pedagogical repertoire that is in line with the learning dynamics of our linguistically diverse students. The key operation is making connections. How is my pedagogical practice ensuring my students can access content? How am I drawing from their background and their linguistic knowledge? How do I get to know my students by drawing from their backgrounds and linguistic knowledge?

And finally, assessment. In a context that places strong emphasis on students' English proficiency, engaging students and educators in authentic assessment that targets content is often a challenge. What languages can my students use in the context of an assessment? What am I assessing? How am I assessing?

\section{Moving Forward}

The collection of studies in this volume represents dialectic possibility. They show the pedagogical potential of expanding dialogue across different divisions at the university and empowering researchers to have a say in local educational policy. The findings from this work have strong implications for institutional language policy and pedagogical practice. The studies share a common understanding of the value of multilingualism in our diverse societies and further illuminate the need to disseminate these findings to inform the work of educators and policy makers. Most importantly, these studies are paving the road to disrupt the traditional lens on language policy and higher education, for they reveal the theoretical and empirical nuances stemming from the process. Further questions around the methodological potential of these issues as well as expanding particular findings provide fertile ground for more research. 
A special acknowledgement to the dedicated and committed group of scholars who devoted their time and passion to these topics as authors and editors, and to the Futures Initiative Directors, Cathy Davidson, Katina Rogers and FI Fellow Michael Dorsch, whose work informed our project.

\section{References}

Carter, R., \& Goodwin, A. L. (1994). Racial identity and education. Review of Research in Education, 20, 291-336. DOI: http://dx.doi.org/10.2307/1167387.

City University of New York: Mission and History. (2016, May $\left.10^{\text {th }}\right)$. Retrieved from http://www2.cuny.edu/about/history/

Garcia, O. (2016). Global perspectives on language and education policy [Class syllabus]. Department of Urban Education, Graduate Center, City University of New York, NY.

Johnson, D. C. (2009). Ethnography of language policy. Language Policy, 8 (2), 139-159. DOI: http://dx.doi.org/10.1007/s10993-009-9136-9.

Ricento, T. (2000). Ideology, politics and language policies: Focus on English. Amsterdam: Benjamin.

Tollefson, J. (2013). (ed.) Language policies in education. Critical issues. New York: Routledge. Vila, X., \& Bretxa, V. (2014). Language policy in higher education: The case of medium-sized languages. Bristol; Buffalo: Multilingual Matters.

Author's information: Carmina Makar is Assistant Professor in the School of Education at The City College of New York. She received her BA in Communication Studies from ITESO University (Mexico) and then established residence in New York as a Fulbright Fellow to pursue graduate studies. She earned her MA in International Education Development with a focus on Bilingual and Bicultural Education from Teachers College, Columbia University and a doctoral degree in International Development from the same institution. As a supervisor and P-12 coordinator, Carmina has also worked around developing clinically rich environments for bilingual educators as well as activating critical education practices across formal and non-formal education spaces. As part of her work with childhood, space and community development, Carmina has served as a consultant for UNESCO and UNDP in issues regarding education and development of children in urban environments.

Email: cmakar@ccny.cuny.edu

${ }^{1}$ See http://futures.gc.cuny.edu/ for more on their work.

To cite this article:

Makar, C. (2016). Uncovering language policy in higher education: Reflections from the classroom. Bellaterra Journal of Teaching \& Learning Language \& Literature, 9(2), 6-13. DOI: http://dx.doi.org/10.5565/rev/jt13.675 